\title{
Seasonal Use of a New England Estuary by Foraging Contingents of Migratory Striped Bass
}

\author{
SARAH M. PAUTZKE ${ }^{1}$ \\ Massachusetts Cooperative Fish and Wildlife Research Unit, Department of Natural Resources Conservation, \\ and School of Marine Sciences, University of Massachusetts, Amherst, Massachusetts 01003, USA \\ Martha E. Mather* \\ U.S. Geological Survey, Massachusetts Cooperative Fish and Wildlife Research Unit, and \\ Department of Natural Resources Conservation and School of Marine Sciences, University of Massachusetts, \\ Amherst, Massachusetts 01003, USA \\ JOHN T. FINN \\ Department of Natural Resources Conservation and School of Marine Sciences, University of Massachusetts, \\ Amherst, Massachusetts 01003, USA
}

Linda A. DeEgan

The Ecosystems Center, Marine Biological Laboratory, Woods Hole, Massachusetts 02543, USA

\author{
RoBert M. Muth \\ Department of Natural Resources Conservation and School of Marine Sciences, University of Massachusetts, \\ Amherst, Massachusetts 01003, USA
}

\begin{abstract}
Using acoustic telemetry on migratory striped bass Morone saxatilis in Plum Island Estuary (PIE), Massachusetts, we found that striped bass (335-634 $\mathrm{mm}$ total length) tagged in the spring and summer of $2005(n=14)$ and $2006(n=46)$ stayed in the estuary for an average of $66.0 \mathrm{~d}$ in 2005 and $72.2 \mathrm{~d}$ in 2006. Striped bass spent the most time in two specific reaches: middle Plum Island Sound and lower Rowley River. In both years, three different use-groups of striped bass were observed in PIE. Short-term visitors $(n=24)$ stayed in the estuary only briefly (range $=5-20 \mathrm{~d}$ ). Two groups of seasonal residents stayed for more than 30 $\mathrm{d}$, either in the Rowley River $(n=14)$ or in Plum Island Sound $(n=22)$. Within PIE, the two seasonal-resident use-groups may be foraging contingents that learn how to feed efficiently in specific parts of the estuary. These distinct within-estuary use patterns could have different implications for striped bass condition and prey impact.
\end{abstract}

The location, timing, and movements of Atlantic coast stocks of striped bass Morone saxatilis can affect their survival, growth, and impact on local prey. The coastal migratory stock spawns primarily in the Chesapeake Bay, Delaware River, or Hudson River (Collette and Klein-MacPhee 2002); many of these migrants then move along the coast in the spring and return in the fall (Clark 1968; Dorazio et al. 1994). Little is known about how these migrants use New England estuaries in summer, even though many striped bass are caught there during their seasonal foraging migration (Berggren and Lieberman 1978; Fabrizio 1987a, 1987b; Mather et al. 2009). Here, we

\footnotetext{
* Corresponding author: mather@nrc.umass.edu

1 Present address: Western Pacific Fishery Management Council, Honolulu, Hawaii 96813, USA
}

Received December 15, 2008; accepted September 12, 2009 Published online December 10, 2009 examined migration timing, duration of estuary use, within-estuary distribution, and individual striped bass behavior in Plum Island Estuary (PIE) in northeastern Massachusetts.

Substantial gaps exist in our understanding of how individual migratory striped bass use estuaries in summer and whether adult distribution varies across coastal systems. Older studies, which are based mostly on single recaptures of externally tagged fish, describe general coastal movements. These studies show that after the spawning season, Atlantic striped bass migrate north along the coast before returning south in the fall to the area where they overwinter (Boreman and Lewis 1987; Waldman et al. 1990). Recent acoustic telemetry studies of other coastal populations (Haeseker et al. 1996; Carmichael et al. 1998; Bjorgo et al. 2000) provide multiple detection data on individual striped bass that inhabit coastal systems. These fish, however, do not typically move long distances north-south along 
the coast. Recent acoustic tagging studies within the natal Hudson River (New York; Wingate and Secor 2007) and the nonnatal Mullica River-Great Bay (New Jersey; Able and Grothues 2007; Ng et al. 2007; Grothues et al. 2009) estuaries provide the first example of multiple-detection movement data for individual striped bass coastal migrants.

For several reasons, migratory striped bass may be distributed differently in PIE than in other estuaries. Like many temperate estuaries, PIE experiences distinct changes in seasonal productivity. Because PIE is located in the middle of the range through which striped bass migrate, is moderately large, and has constricted connections to the ocean, migratory striped bass may experience different conditions in this system than in other estuaries they encounter. To quantify where striped bass tagged in PIE spend their time during their summer foraging migration, we used acoustic telemetry on 60 adult migratory striped bass over the span of 2 years. First, we assessed how long and in what season individual striped bass used PIE. Second, we determined whether striped bass spent equal time in all reaches of the estuary or whether they favored specific locations. Third, we examined whether distribution within PIE changed with season. Fourth, we identified whether individual striped bass belonged to distinct behavioral groups that had different movement patterns. Finally, we integrated our results with recent telemetry studies on coastal migratory striped bass to recommend standardized metrics for future across-system comparisons.

\section{Study Area}

Plum Island Estuary (Figure 1A) is the largest saltmarsh-dominated estuary in New England. This coastal plain, bar-built estuary has extensive marshes and is composed of three freshwater rivers (Parker, Rowley, and Ipswich rivers), one tidal river that serves as a connection to the ocean (Plum Island River), multiple tidal creeks (TCs), and a large embayment-Plum Island Sound (Figure 1B). This ecosystem is vertically well mixed and has a large semidiurnal tidal range (2.9 m) with low freshwater input (Deegan and Garritt 1997; Vallino et al. 2005). The water body area of the entire estuary ranges from $12.8 \mathrm{~km}^{2}$ (low tide) to 20.0 $\mathrm{km}^{2}$ (high tide), with extensive areas of nonvegetated tidal flats exposed at low tide.

To acoustically track striped bass, we divided PIE into two areas: Plum Island Sound, the wide, open area that is closest to the ocean (length $=8 \mathrm{~km}$ ); and the Rowley River (RR), a narrower area with a welldefined channel that is fed by numerous TCs (length $=$ $7.6 \mathrm{~km}$ ). Each of these two areas is further divided into three reaches. Except for the TCs, all reaches had a similar length, although reach areas were generally larger in the sound than in the river (Table 1; Figure 1B). Lower Plum Island Sound, the southernmost reach within the Plum Island Sound area, is deep and relatively wide and has hard substrates. Lower Plum Island Sound includes both the primary southern connection with the ocean and the mouth of the Ipswich River. The second reach within the Plum Island Sound area (middle Plum Island Sound) is shallower and wide and also has hard substrates. Middle Plum Island Sound includes both the confluence with the RR and Middle Ground Island, a tidally influenced island with a salt-marsh landscape. The third reach (upper Plum Island Sound) is deep, is wide in places, and contains varied substrates. This northern reach includes the confluence with the deeper Parker River as well as a connection to the Atlantic Ocean via the Plum Island River.

The first reach within the RR area (lower RR) is moderately deep and narrow and has a combination of hard and soft substrates (Table 1; Figure 1B). The lower RR reach includes the confluences of numerous, small, unnamed TCs; is adjacent to Plum Island Sound; and includes the mouth of the RR. The second reach in the RR area (upper RR) is shallower, narrower, and characterized by muddy substrates. The last reach within the RR (RR TCs) is composed of two unconnected, named TCs (West and Clubhead creeks) that are very shallow and narrow and have soft sediments. The width and depth of all three RR reaches vary greatly with tidal stage.

\section{Methods}

Tagging.-We used VEMCO V13-1H-R256 coded hydroacoustic tags. Tags had a frequency of $69 \mathrm{kHz}$ and a ping rate of $20-90 \mathrm{~s}$ in 2005 and $40-120 \mathrm{~s}$ in 2006. The average tag life was $100 \mathrm{~d}$ in 2005 and $275 \mathrm{~d}$ in 2006. The weight of the acoustic tags (6.6 $\mathrm{g}$ in water) was less than $1.8 \%$ of the mass of the lightest tagged striped bass (368 g) and less than $0.8 \%$ of the mean mass of all tagged fish (789 g). Striped bass were caught via daytime hook-and-line fishing on an ebb tide in the middle Plum Island Sound and lower RR reaches. In 2005, 14 striped bass (mean total length $[\mathrm{TL}]=418.9 \mathrm{~mm} ; \mathrm{SE}=15.2 \mathrm{~mm}$; range $=335-510$ $\mathrm{mm}$ ) were caught and tagged in three batches from mid-July through late August (Figure 2). In 2006, 46 fish (mean $\mathrm{TL}=433.7 \mathrm{~mm}$; $\mathrm{SE}=7.6 \mathrm{~mm}$; range $=$ 380-634 mm) were tagged in two batches (May 27-29 and July 6-7). In 2006, we specifically targeted the 400-500-mm size-class, which was the most common size in PIE. Based on a size-at-age key for fish caught in Massachusetts waters, these striped bass were 2-6 years old (mostly 3-5 years old; G. Nelson, personal 

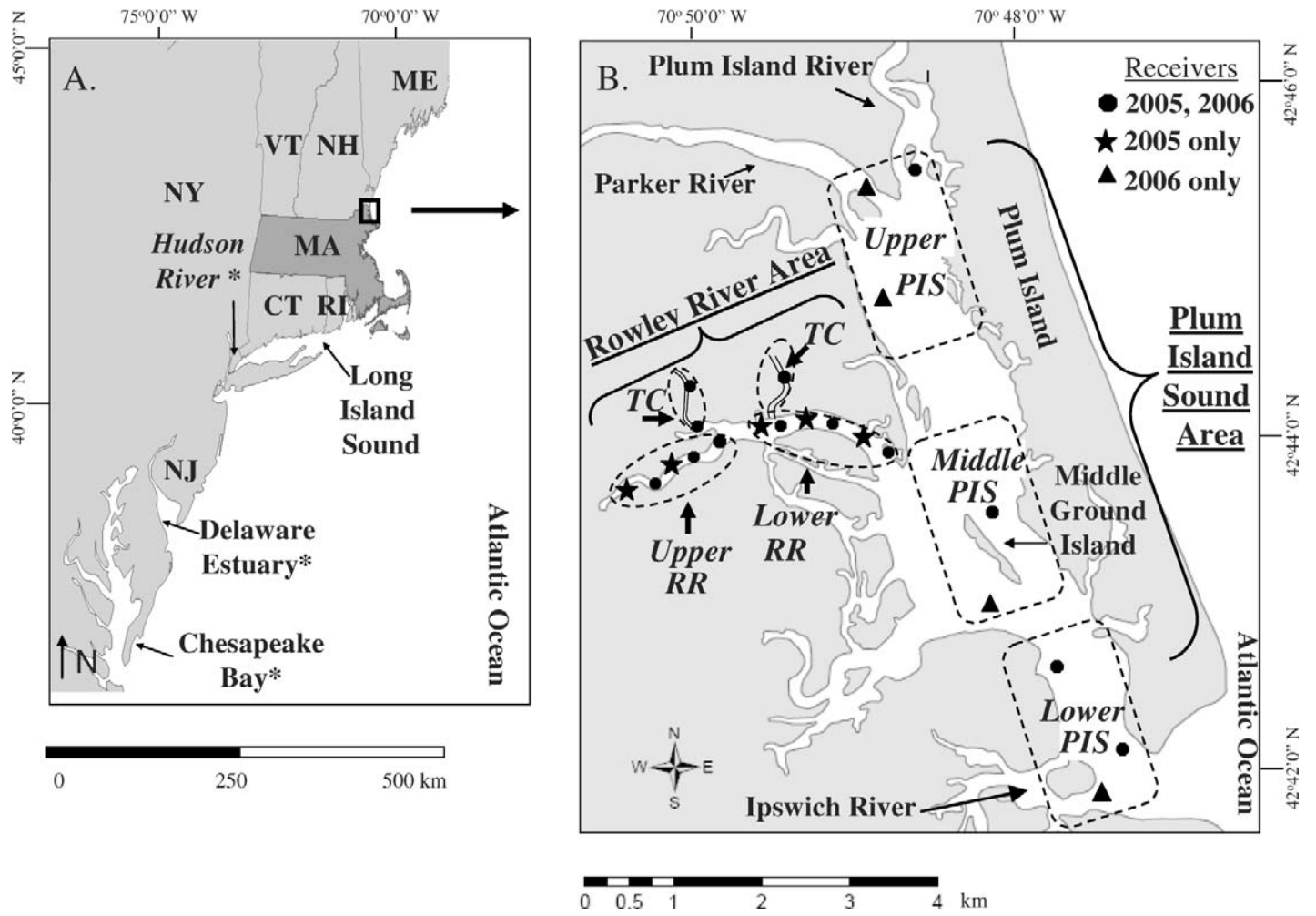

FIGURE 1.-(A) Location of Plum Island Estuary (PIE) in northeastern Massachusetts within the northern portion of the migratory range of coastal striped bass. Also shown are telemetry arrays in Long Island Sound and Delaware River Estuary, where our tagged striped bass were detected (H. Brundage, D. Fox, and T. Savoy, personal communication). The Hudson River, Delaware River, and Chesapeake Bay (three important spawning locations) are indicated with asterisks. (B) The PIE was divided into two study areas that each contained three reaches: the Rowley River (RR) area (upper RR, lower RR, and tidal creek [TC] reaches) and the Plum Island Sound (PIS) area (upper, middle, and lower PIS reaches). Dots represent receiver sites used in both 2005 and 2006; stars represent sites that were used only in 2005; and triangles indicate sites that were used only in 2006. Measurements of each reach are shown in Table 1.

communication). The spawning origin of these fish is unknown.

After capture, fish were held in a large, continually aerated holding tank $(378.5 \mathrm{~L} ; 1.30 \times 0.79 \times 0.64 \mathrm{~m})$. Using clove oil as the anesthetic $(1.5 \mu \mathrm{L}$ of clove oil/L of water; mean application time $=7.8 \mathrm{~min}, \mathrm{SE}=1.6$ min; Ferry 2003; Cooke et al. 2004), fish were first weighed ( $\mathrm{g}$ ) and measured (TL, mm). Tags were then surgically implanted (Bridger and Booth 2003) using a sterile scalpel to make a small, 2-3-cm-long incision 2 $\mathrm{cm}$ above the ventral midline and approximately 1.5 $\mathrm{cm}$ behind the pelvic fin. Through this opening, we

TABLE 1.-Physical attributes of two study areas and six reaches used to quantify within-estuary distribution of migratory striped bass in Plum Island Estuary, Massachusetts. Shown are area name, reach name, length, area, average depth (midtide), average width (midtide), substrate, and geographic orientation. All locations are shown in Figure 1.

\begin{tabular}{|c|c|c|c|c|c|c|c|}
\hline Area name & Reach name & $\begin{array}{l}\text { Length } \\
(\mathrm{km})\end{array}$ & $\begin{array}{l}\text { Area } \\
\left(\mathrm{km}^{2}\right)\end{array}$ & $\begin{array}{l}\text { Average } \\
\text { depth }(\mathrm{m})\end{array}$ & $\begin{array}{c}\text { Average } \\
\text { width }(\mathrm{km})\end{array}$ & Substrate & $\begin{array}{l}\text { Geographic } \\
\text { orientation }\end{array}$ \\
\hline \multirow[t]{3}{*}{ Plum Island Sound (PIS) } & Lower PIS & 2.4 & 1.97 & 4.7 & 0.73 & Rock, sand & Southern \\
\hline & Middle PIS & 3.0 & 3.96 & 1.8 & 1.51 & Sand, shellfish beds & Middle \\
\hline & Upper PIS & 2.6 & 2.91 & 5.7 & 0.5 & Sand, mud, mussel beds & Northern \\
\hline \multirow{3}{*}{ Rowley River (RR) } & Lower RR & 2.3 & 0.52 & 3.0 & 0.17 & Sand, mud, shellfish beds & Downstream \\
\hline & Upper RR & 3.4 & 0.19 & 2.5 & 0.042 & Mud & Upstream \\
\hline & Tidal creeks ${ }^{\mathrm{a}}$ & 1.9 & 0.06 & 1.0 & 0.03 & Mud & North of RR main stem \\
\hline
\end{tabular}

\footnotetext{
${ }^{\mathrm{a}}$ West and Clubhead creeks.
} 
Tagging and Detection Dates for Migratory Striped Bass in PIE (2005-2006)

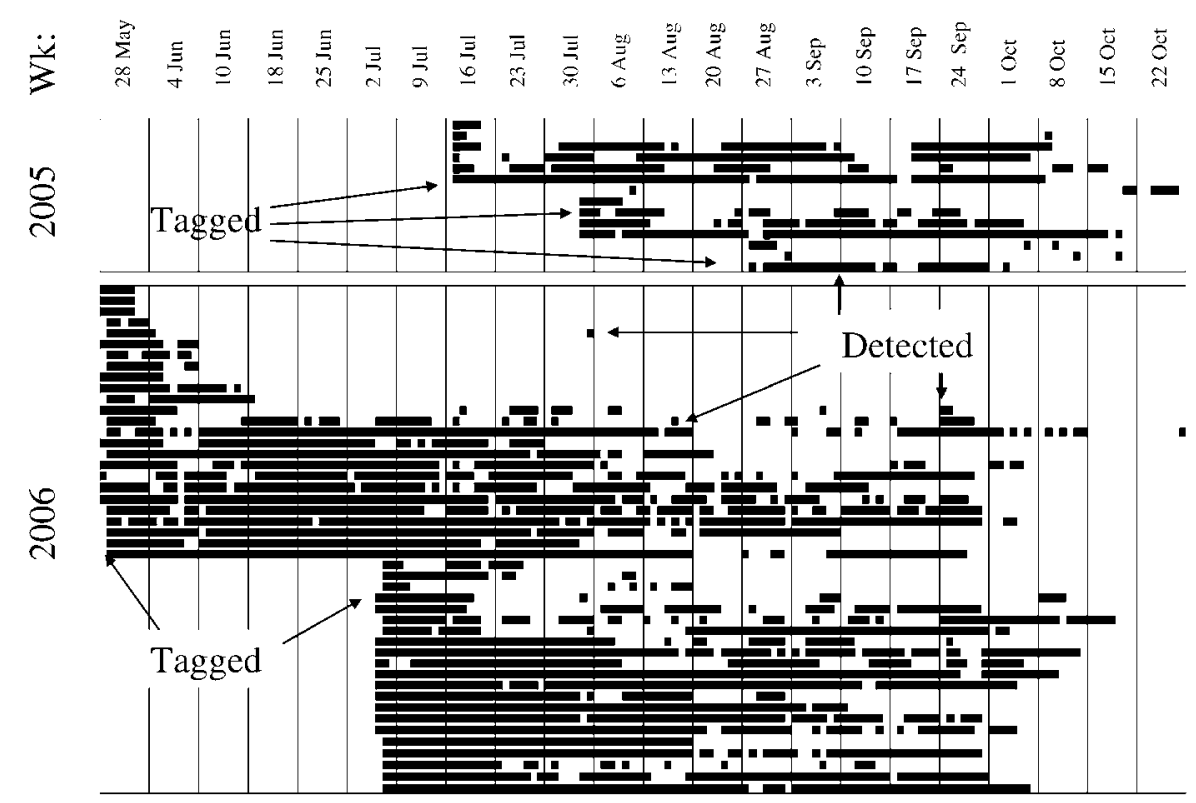

FIGURE 2.-Dates when migratory striped bass were tagged and detected in Plum Island Estuary (PIE), Massachusetts, during 2005 (top of figure) and 2006 (bottom of figure). Dates along the top indicate the beginning of each week of data collection. Each horizontal line represents 1 of 60 fish. Filled cells represent days when fish were detected in PIE. Horizontal patterns indicate variations in consecutive and nonconsecutive days of detection in PIE. Not all fish were detected on the day of tagging.

inserted the tag into the peritoneal cavity and closed the incision with Monocryl dissolvable sutures using a cutting needle. Equipment and tags were sterilized with Betadine (Szedlmayer and Schroepfer 2005). To reduce stress during surgery, the gills and external body surface were irrigated at all times with estuary water and the measuring board was kept moist. After tagging, each striped bass was placed in a cylindrical recovery tank (113 L; 0.6-m diameter $\times 0.6-\mathrm{m}$ depth) filled with ambient estuary water until the fish swam upright (mean $=8.3 \mathrm{~min} ; \mathrm{SE}=1.2 \mathrm{~min}$ ). The entire tagging process took, on average, $11.0 \mathrm{~min}(\mathrm{SE}=1.0 \mathrm{~min}$ ). During the three tagging sessions in 2005, fish were tagged $4.5 \mathrm{~km}$ upstream of the RR mouth, held overnight to assess posttagging mortality, and then released on the morning ebb tide. In 2006, fish were tagged where they were caught, given a dose of injectable Liquamycin antibiotic $(0.1 \mathrm{mg} / \mathrm{kg}$ of fish; Pfizer, Inc., New York, New York), and released immediately after tagging.

Control experiments.-We used several methods to assess whether striped bass survived tagging. First, in 2005 , we held tagged striped bass in net-pens $(0.75-\mathrm{m}$ diameter $\times 1-\mathrm{m}$ height) for $12-15 \mathrm{~h}$ after tagging. Second, in 2006, we held three pairs of tagged and untagged fish (mean TL $=451 \mathrm{~mm} ; \mathrm{SE}=11 \mathrm{~mm}$ ) in separate cylindrical holding pens $(1.2-\mathrm{m}$ diameter $\times$ 1.2-m depth) in the RR for $6 \mathrm{~d}$. To further assess possible mortality related to tagging, we evaluated three additional responses: (1) the minimum number of days that tagged fish were present in PIE, (2) whether fish tagged in 2005 were detected again in PIE in 2006, and (3) whether tagged fish were detected in other telemetry arrays along the coast. We assumed that if fish were detected and moving for months, they were not adversely affected by tagging.

Receivers.-We placed receivers throughout the six reaches within the two areas of PIE to provide extensive coverage with minimal overlap. We deployed 18 VEMCO VR20 receivers in 2005 and 17 VR20 or VR1 receivers in 2006 (Figure 1B). The VR20s (2005: $n=18$; 2006: $n=9$ ) were anchored to the bottom; the VR1s (2006: $n=8$ ) were suspended 1 $\mathrm{m}$ below the water surface. All receivers were moored such that the hydrophone pointed up. In 2005, receivers were deployed from July 16 to November 18 and were able to detect fish for a maximum of $125 \mathrm{~d}$. In 2006, receivers were deployed from May 25 to November 18 and were able to detect fish for a maximum of $177 \mathrm{~d}$. Receivers were removed in fall (mid-November), 2 
weeks after the last fish was detected. Although withinestuary use was the focus of this study, we also identified the receiver at which each fish was last detected and we examined whether tagged fish passed receivers sequentially as they exited the study area.

We assessed the site-specific range of each receiver by moving a tag away from each fixed receiver at high and low tides. By inputting times of tag detection and Global Positioning System tracks into ArcGIS, we created starburst plots of receiver ranges at low and high tides. Based on this, we constructed polygons in ArcView to quantify the areas that each receiver heard at high, low, and average tides. The mean receiver range across all tides was $0.08 \mathrm{~km}^{2}\left(\mathrm{SE}=0.02 \mathrm{~km}^{2}\right)$, with differences related primarily to local bottom topography.

Each receiver in the array recorded the tag code, detection date, and detection time of each fish within its detection range. Because the thousands of detections for each fish at each receiver were not independent, we aggregated these data into the amount of time (h) each fish spent at each receiver. We termed this variable "duration" and calculated it by totaling the time between the first observation and last observation at a receiver for observations $15 \mathrm{~min}$ apart or less. This eliminated temporally correlated detection data at any single receiver. Duration data were divided by range size so that data from all receivers represented a standardized area. Occasionally, receivers did not detect fish because of dead batteries. For this reason, data were further standardized temporally so that all receiver data represented a common time period each year.

Analyses.-Prior to statistical analyses, we ensured that fish passed each functional receiver in sequence and discarded all single-hit data (Clements et al. 2005). In 2005, to compensate for the release of striped bass 4 $\mathrm{km}$ from their catch site, data for the first $4 \mathrm{~d}$ posttagging were not used. Duration data were combined for all receivers within each of the six reaches to reduce the number of zeros in the data set. Coverage in each reach was calculated by summing the standardized ranges of all receivers within a reach. To determine whether striped bass resided in PIE seasonally or were just passing through, we examined residence time or how many total days (not necessarily consecutive) that each fish was detected in PIE by subtracting the tagging date from the date the fish was last detected in PIE. Polythetic agglomerative hierarchical clustering on untransformed data was used with Ward's linkage to determine whether different groups of fish were using PIE for different amounts of time (e.g., short-term visitors versus seasonal residents). Ward's linkage minimizes the between-cluster sum of squares divided by the total sum of squares, which is referred to as the semipartial $R^{2}$ (Legendre and Legendre 1998). For the seasonal resident group, we used a one-sample Kolmogorov-Smirnov (K-S) goodness-of-fit test (Zar 1984) to compare observed data (time spent in each reach) with the distribution that would be expected if striped bass used each estuary location equally (i.e., detected one-sixth of their time in each reach). To assess whether all individual fish behaved similarly or whether there were different groups of seasonal residents, we ran a second agglomerative hierarchical cluster analysis (Ward's linkage) on the amount of time fish were detected in both the Plum Island Sound and RR areas. We used a two-population $\mathrm{K}-\mathrm{S}$ test and a multivariate analysis of variance (MANOVA) to test whether (1) all fish or (2) groups of seasonal residents differed in their use of the six estuary reaches. We then evaluated potential reasons for differences among use-group distributions, such as tagging date, departure date, and fish size.

Finally, we examined whether striped bass distribution across reaches changed by season using a twopopulation $\mathrm{K}-\mathrm{S}$ test and a repeated-measures (RM) analysis of variance (ANOVA; Sokal and Rohlf 1995; Quinn and Keough 2002). Spring was defined as May and June, summer was defined as July and August, and fall was defined as September and October based on general shifts in water temperatures and day length. In all analyses, the experimental unit was the fish (White and Garrott 1990; Rogers and White 2007). For two responses (residence time and within-estuary distribution), we show data for 2005 and 2006. For four analyses (the two cluster analyses, within-estuary distribution of foraging contingents, and seasonal differences), we only show data for striped bass tagged in 2006 .

\section{Survival}

\section{Results}

Tagged striped bass survived and continued to move around the estuary and along the coast. In 2005, the 14 striped bass held overnight were alive and healthy at release $(\sim 12-15 \mathrm{~h}$ posttagging). The three pairs of tagged and untagged fish that were held for $6 \mathrm{~d}$ in 2006 survived similarly (100\%). For these caged fish, no evidence of tagging stress was observed. All 60 striped bass tagged in both years were detected in PIE for a minimum of $6 \mathrm{~d}$ after tagging (Figure 2). In the year of tagging, striped bass remained in PIE from 6 to $96 \mathrm{~d}$ in 2005 and from 6 to $122 \mathrm{~d}$ in 2006. Nine of the 14 striped bass tagged in 2005 were detected in PIE again in 2006, at least $215 \mathrm{~d}$ after tagging. Finally, 36 of the 60 striped bass that we tagged, including some detected for only a few days in PIE, were detected in other 
arrays along the Atlantic coast (i.e., Long Island Sound, Delaware Bay Estuary; Figure 1A) during their southern migration, 90-470 d after tagging $(\mathrm{H}$. Brundage, Environmental Research and Consulting, Inc., personal communication; D. Fox, Delaware State University, personal communication; T. Savoy, Connecticut Department of Environmental Protection, personal communication). Thus, in both 2005 and 2006, all fish survived the control experiments. In addition, all tagged fish (1) were detected in PIE for an extensive period during the tagging year, (2) returned to PIE the year after tagging, or (3) were detected elsewhere along the coast during the winter after tagging.

\section{Short-Term Visitors versus Seasonal Residents}

Some fish remained in PIE for only a short time, while others were seasonal residents. Coastal migratory striped bass tagged and released in PIE stayed an average of $66.0 \mathrm{~d}$ in 2005 ( $\mathrm{SE}=7.6 \mathrm{~d}$ ) and $72.2 \mathrm{~d}$ in $2006(\mathrm{SE}=6.2 \mathrm{~d})$. A cluster analysis of total days for which fish tagged in 2006 resided in PIE separated fish into two groups: those that stayed more than $30 \mathrm{~d}$ within PIE, and those with a residence time less than 30 d (Figure 3A). Of the 14 fish tagged in 2005, 50\% stayed within PIE for more than 30 d. In 2006, 29 of 46 striped bass $(63 \%)$ stayed within PIE for more than 30 $\mathrm{d}$ (Figure 3B). All striped bass exited the study area by October 31 in each year (Figure 2). We refer to fish that stayed more than $30 \mathrm{~d}$ as "seasonal residents" and those fish that stayed less than $30 \mathrm{~d}$ as "short-term visitors." Relative to connectivity of movements, 41 of 46 fish in 2006 left PIE via the series of receivers that gated the estuary. Of these, all but one fish exited via the southern entrance to Plum Island Sound. Of the short-term visitors $(n=17)$, all but one were last detected at one of the three southernmost receivers.

\section{Striped Bass Distribution within Plum Island Estuary}

Striped bass were not evenly distributed across the six PIE reaches (K-S test and MANOVA on reaches: 2005, not significant; 2006, $P<0.0001$ ). Instead, tagged striped bass spent the most time in the lower RR and middle Plum Island Sound reaches in both years (Figure 4). Possibly because of a small sample size in 2005, distributional patterns were only statistically significant in 2006. For striped bass that stayed in PIE more than $30 \mathrm{~d}$, a cluster analysis identified two distinct groups of seasonal residents (Plum Island Sound versus RR use-groups; Figure 5A). These seasonal residents differed in the duration of detection in the Plum Island Sound area versus the RR area (Figure 5B). The RR use-group and the Plum Island Sound use-group were unevenly distributed across the six reaches (MANOVA: 2006 only, $P<0.0001$ ). One use-group (RR seasonal residents) spent the most time in the lower RR reach (Figure 6A). A second use-group (Plum Island Sound seasonal residents) spent the most time in the middle Plum Island Sound reach (Figure $6 \mathrm{~B}$ ). The third use-group (short-term visitors; $<30 \mathrm{~d}$ in PIE) roved throughout the entire estuary-albeit only briefly-prior to exiting the estuary (Figure 6C). We do not know why fish formed these three use-groups; however, we know it was not due to differences in date of capture, date of fish departure, or fish size. Fish in all three use-groups were caught and tagged in all time periods; individuals in all three use-groups left PIE in all time periods (Pautzke 2008). Furthermore, striped bass in all three use-groups were of similar size (K-S test: $2005, P=0.53 ; 2006, P=0.31)$.

\section{Seasonal Distribution}

The length of time spent by the three use-groups in each location varied statistically across season for all reaches (RM ANOVA: $P \leq 0.05$ ) except lower Plum Island Sound. In all three seasons (spring, summer, and fall), the Plum Island Sound use-group used the three Plum Island Sound reaches more than the other two use-groups (Figure 7A-C). Their use of upper Plum Island Sound peaked in spring (Figure 7C), and their use of middle Plum Island Sound peaked in summer (Figure 7B). Compared with the other two use-groups, the RR use-group spent the most time in the RR reaches in all three seasons (Figure 7D-E). Use of the lower RR reach by the RR use-group peaked in summer, when they used this reach approximately $96 \%$ of the time (Figure 7D). Time spent in the upper RR reach by the RR use-group was highest in spring (they used this reach $39 \%$ of the time; Figure 7E). The RR fish used the named TCs less than other locations and ceased this limited use altogether in the fall.

\section{Discussion}

Using acoustic telemetry, our study has expanded what is known about habitat use and movements of migratory striped bass in estuaries. Specifically, our results showed that (1) some migratory striped bass stayed in the tagging estuary for a prolonged period, whereas others passed quickly through this estuary; (2) striped bass distribution within PIE was nonrandom; (3) these patterns of distribution changed seasonally; and (4) different use-groups may represent foraging contingents. Much is still unresolved about how striped bass use the gradient of estuarine systems along the Atlantic coast. Viewed together, the existing acoustic telemetry studies on coastal striped bass (Able and Grothues 2007; Ng et al. 2007; Wingate and Secor 2007; Grothues et al. 2009) and the present study 


\section{Length of Estuary Stay by Short-Term Visitors and Seasonal Residents (2006)}
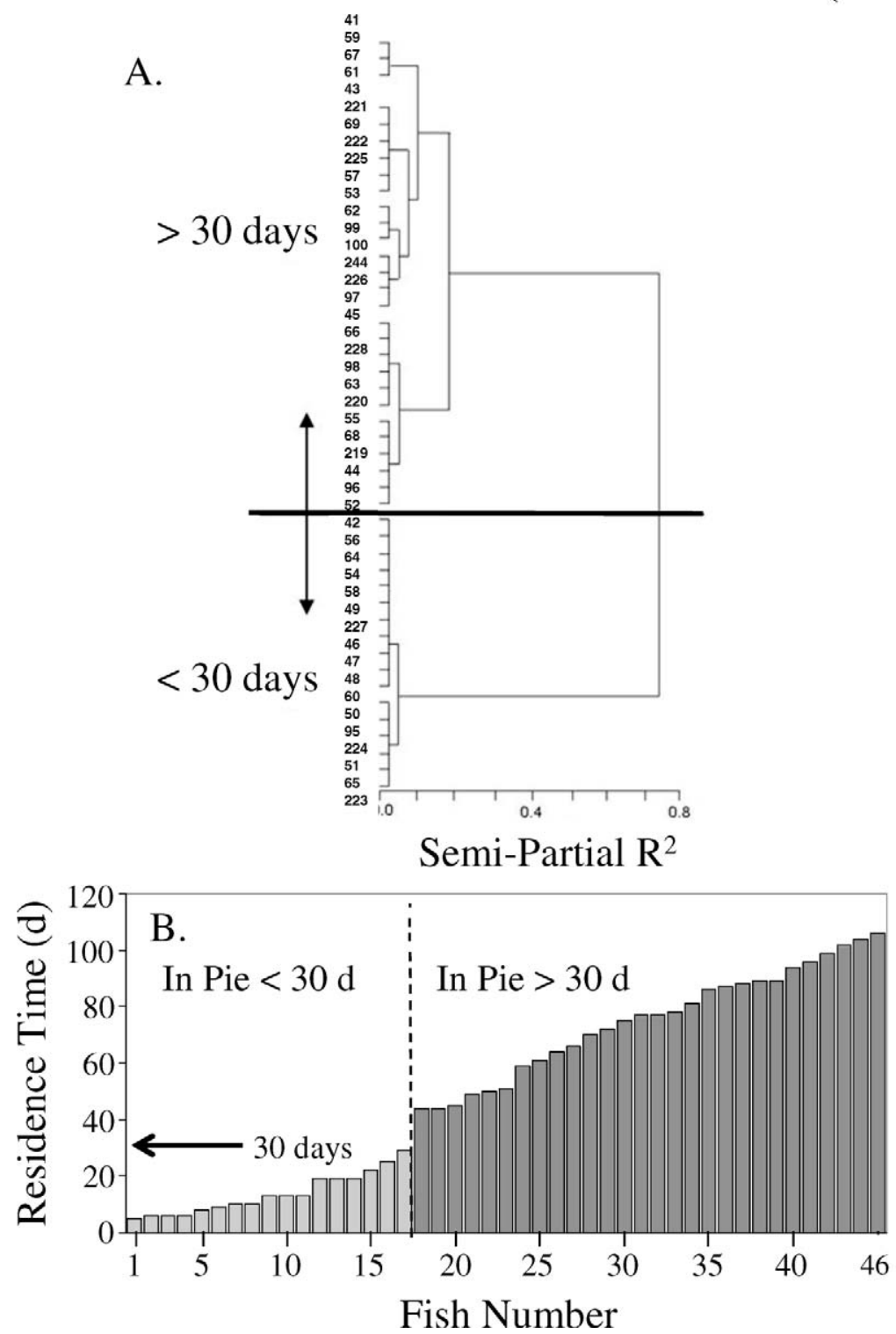

FIGURE 3.-Identification of short-term visitors and seasonal residents in Plum Island Estuary (PIE), Massachusetts, among migratory striped bass tagged during 2006: (A) results of a cluster analysis based on residence time (difference between the date of tagging and the date of final detection in PIE), showing fish that stayed in PIE for more than $30 \mathrm{~d}$ (i.e., seasonal residents; above bold horizontal line) and fish that stayed in PIE for less than $30 \mathrm{~d}$ (i.e., short-term visitors; below the bold horizontal line). Clusters are separated based on semipartial $R^{2}$. Fish are identified by tag numbers. (B) Distribution of short-term visitors $(<30 \mathrm{~d})$ and seasonal residents $(>30 \mathrm{~d})$ based on residence time in PIE is presented. The dotted vertical line separates the two clusters.

provide new insights about the complex movements of these long-distance migrants along the coast and within estuaries. If researchers adopt common summary metrics for identifying seasonal timing of residency (e.g., total days, consecutive days, days by season), detection time, within-system distribution (e.g., individuals, catch per unit effort), abiotic and biotic structure of the estuary, and behaviors of individual 


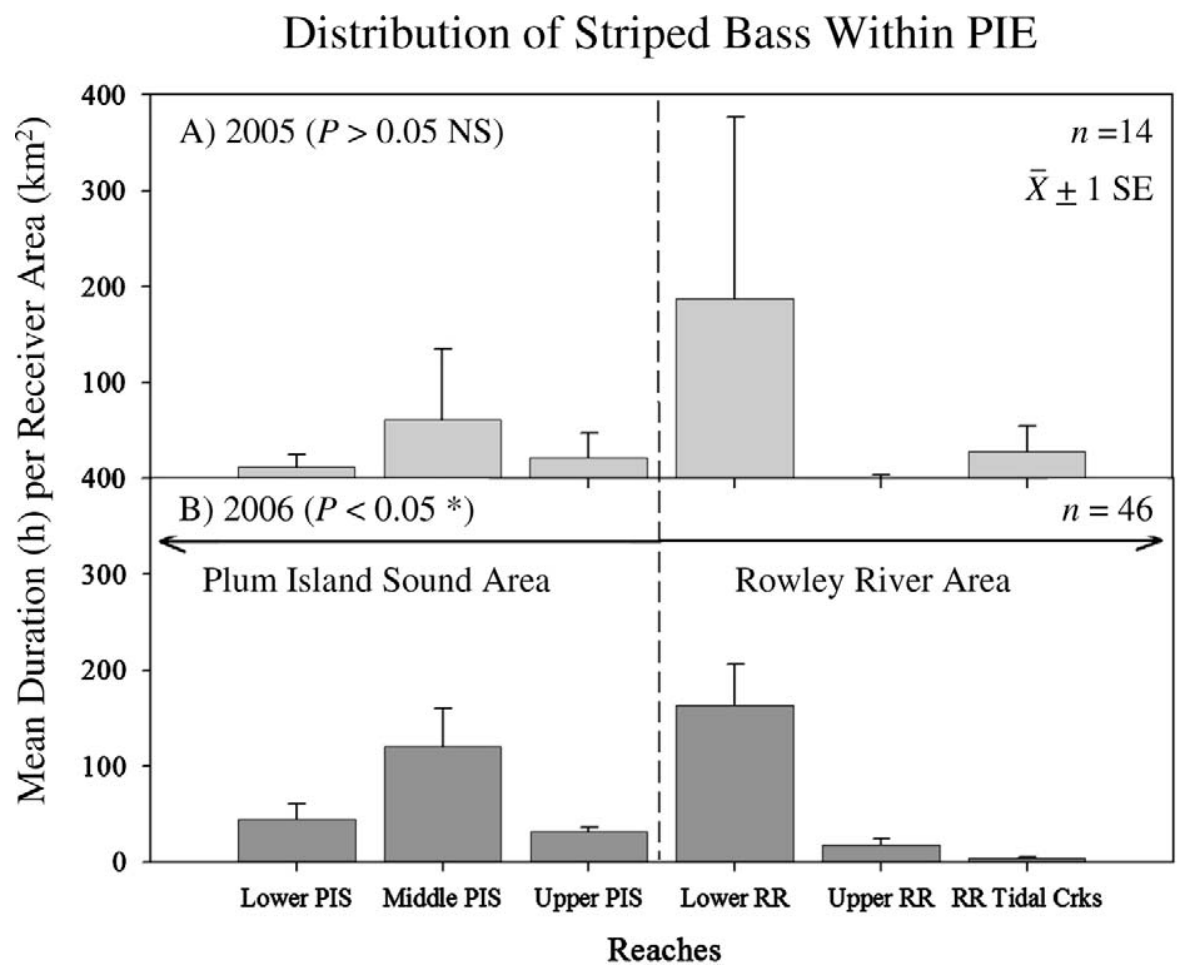

FIGURE 4.- Mean time (h) spent in six reaches of the Plum Island Estuary (PIE), Massachusetts, by striped bass tagged during (A) 2005 ( $n=14$ fish) and (B) 2006 ( $n=46$ fish); three reaches were within the Plum Island Sound (PIS) area (lower, middle, and upper PIS reaches), and three reaches were within the Rowley River (RR) area (upper RR, lower RR, and RR tidal creek reaches). Durations represent the hours fish were detected per standardized area and time of receiver coverage within each reach. Vertical dotted line separates data for the PIS and RR areas.

fish, future comparative coastal studies could provide useful scientific insights for understanding and managing striped bass and other migratory fish.

Although we do not know the natal origin of our tagged striped bass, four lines of evidence suggest that the fish we tagged were not permanent residents of PIE. First, even though some spawning occurs in striped bass populations in many estuaries along the Atlantic coast, historically Chesapeake Bay and the Hudson River have been the primary contributors to the Atlantic coast striped bass fishery. Second, striped bass are seasonally abundant in Massachusetts as few fish are caught in late fall, winter, or early spring and many fish are caught in summer (Mather et al. 2009). Third, in a prior study using anchor tags, most striped bass tagged in Massachusetts during summer were caught south of the tagging location in the fall and winter, the time of the southern migration (Mather et al. 2009). Finally, 36 of the 60 fish we acoustically tagged were detected by southern arrays (Long Island Sound and Delaware Bay Estuary) in the fall and winter, coinciding with the time of southward migration $(\mathrm{H}$.
Brundage, D. Fox, and T. Savoy, personal communication).

\section{Duration of Within-Estuary Residence}

Through the summers of 2005 and 2006, many of our tagged migratory striped bass stayed in PIE for a prolonged period (i.e., an average of 66.0-72.2 d across years). Previous research has established that striped bass reside seasonally in other Atlantic coast estuaries, but the number of fish, detections, and timing vary with methodology, migratory status, estuary characteristics, season of detections, and how the data are reported. Because external tags are recaptured very few times, early tag-recapture studies (Clark 1968; Waldman et al. 1990; Dorazio et al. 1994) provide few insights into how long individuals reside in specific estuaries. Various telemetry studies have elucidated estuary use by migratory striped bass. In the Hudson River, resident contingent striped bass remained in the freshwater tidal river for an average of $172 \mathrm{~d}$ (Wingate and Secor 2007). In the nonnatal Mullica River-Great Bay Estuary, migratory striped bass stayed in the 


\section{Seasonal Residents (2006)}
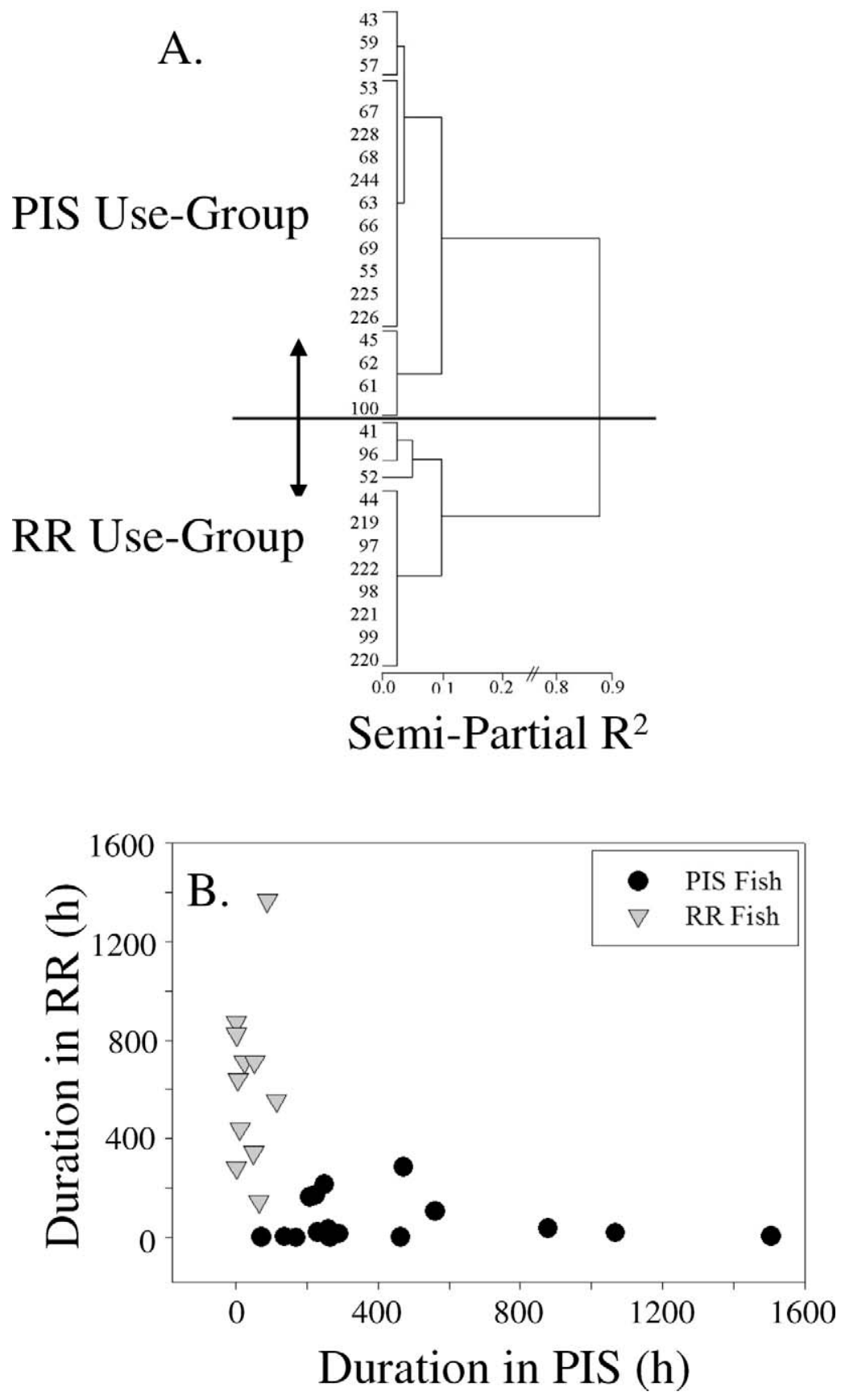

FIGURE 5.-Identification of two use-groups (foraging contingents) among striped bass tagged during 2006 that stayed in Plum Island Estuary (PIE), Massachusetts, for more than $30 \mathrm{~d}$ (seasonal residents; identified in Figure 3): (A) results of a cluster analysis indicating use-groups for the Plum Island Sound (PIS) and Rowley River (RR) areas based on the hours of fish detection at receivers within those areas. Clusters are separated based on semipartial $R^{2}$. Fish are identified by tag numbers. (B) Duration of time (h) spent in the PIS and RR areas is presented (black dots = PIS use-group; gray inverted triangles $=$ RR use-group). 
Use-Groups (Foraging Contingents) 2006)

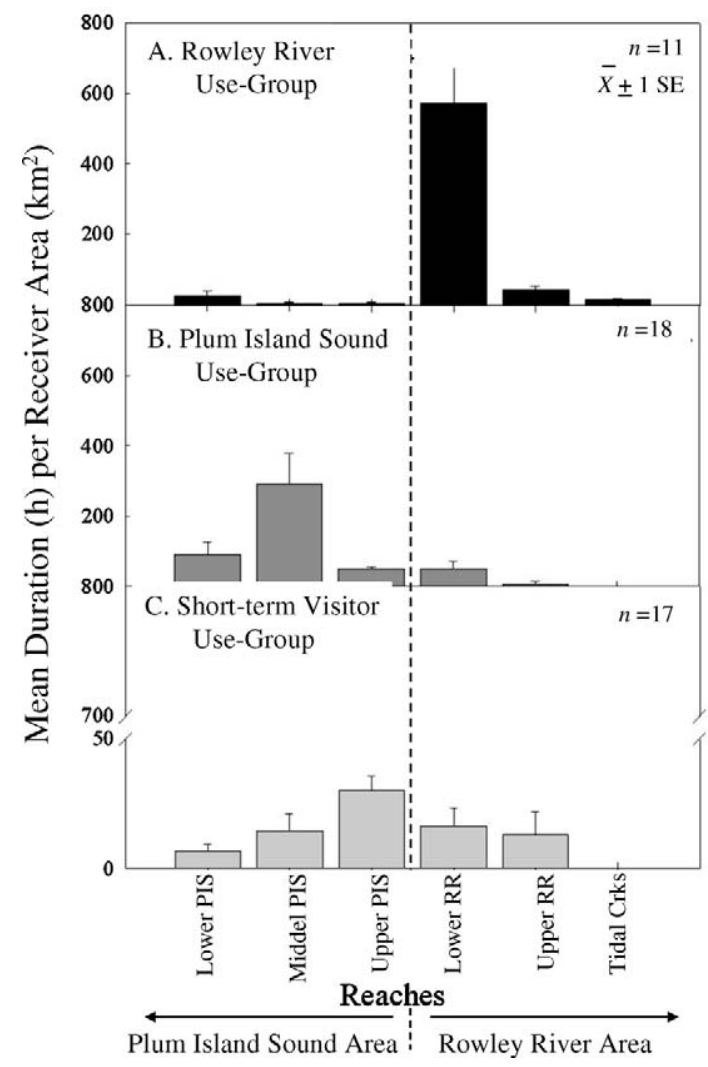

Figure 6.-Mean time (h) spent in six reaches of the Plum Island Estuary, Massachusetts, by three use-groups (foraging contingents) of striped bass tagged during 2006: (A) Rowley River (RR) use-group; (B) Plum Island Sound (PIS) usegroup; and (C) short-term visitor use-group. Three reaches were within the PIS area (lower, middle, and upper PIS reaches), and three reaches were within the RR area (upper $\mathrm{RR}$, lower RR, and RR tidal creek reaches). Durations represent the hours spent per standardized area and time of receiver coverage within each reach. Vertical dotted line separates data for the PIS and RR areas.

estuary for an average of 20.0-43.5 d/year, primarily in the spring and fall (Able and Grothues 2007), a pattern consistent with temporary use of the nonnatal system by migratory striped bass. However, mobile telemetry also revealed that some individual striped bass stayed in this same estuary for an extended period ( $\mathrm{Ng}$ et al. 2007). Thus, although the number of days and season of detection vary across locations, there is consistency across studies in that estuaries provide either a destination or a stopover during migration.

\section{Patterns of Within-Estuary Distribution}

The striped bass we tagged were distributed in a heterogeneous pattern within PIE. Although we do not know why striped bass disproportionately used the lower RR and middle Plum Island Sound reaches, their distribution was not related solely to reach size or length (Pautzke 2008). The lower RR area included mouths to numerous TCs and a complex bottom structure. The middle Plum Island Sound area included heterogeneous habitat as well as a large, tidally exposed island (Middle Ground Island). Consequently, the lower RR and middle Plum Island Sound reaches could have been attractive to feeding striped bass because of estuarine bathymetry, water movement, temperature, or prey distribution.

Results of other acoustic research on migratory striped bass (Able and Grothues 2007; Ng et al. 2007; Wingate and Secor 2007) also indicate that striped bass are clustered in specific locations, although patterns vary across estuaries. Across estuaries, the distribution of adult striped bass is influenced by a suite of abiotic and biotic factors. Distribution of striped bass is often related to temperature, bathymetry, and prey. Within estuaries, temperature influences nonspawning striped bass distribution (Coutant and Benson 1990; Bjorgo et al. 2000; Able and Grothues 2007; $\mathrm{Ng}$ et al. 2007; Wingate and Secor 2007). In many estuaries, striped bass concentrate near shorelines ( $\mathrm{Ng}$ et al. 2007), structures (Haeseker et al. 1996), creek mouths (Waldman et al. 1990; Tupper and Able 2000), and other complex habitats (confluences, mussel beds; Harding and Mann 2003). Striped bass are generalist feeders that consume forage fish and invertebrates (Hartman and Brandt 1995; Ferry 2003; Nelson et al. 2003; Walter et al. 2003). Thus, within-estuary distribution may be related to temperature, habitat, or prey.

\section{Seasonal Changes in Distribution}

Within-estuary distributions changed seasonally. Striped bass in the Plum Island Sound use-group utilized several reaches throughout PIE during the spring but predominately settled into a single reach during the summer. Rowley River fish spent more than $93 \%$ of their time in the RR during spring and summer, but their use of the river dropped in the fall. This change in fall distribution was also observed in other acoustic studies of migratory striped bass $(\mathrm{Ng}$ et al. 2007) and may be in preparation for their movement out of the estuary or in response to changes in temperature and prey.

\section{Use-Groups (Foraging Contingents)}

The three use-groups identified in PIE (i.e., shortterm visitors, RR seasonal residents, and Plum Island Sound seasonal residents) did not differ consistently by tagging date, departure date, or fish size. If use-groups 


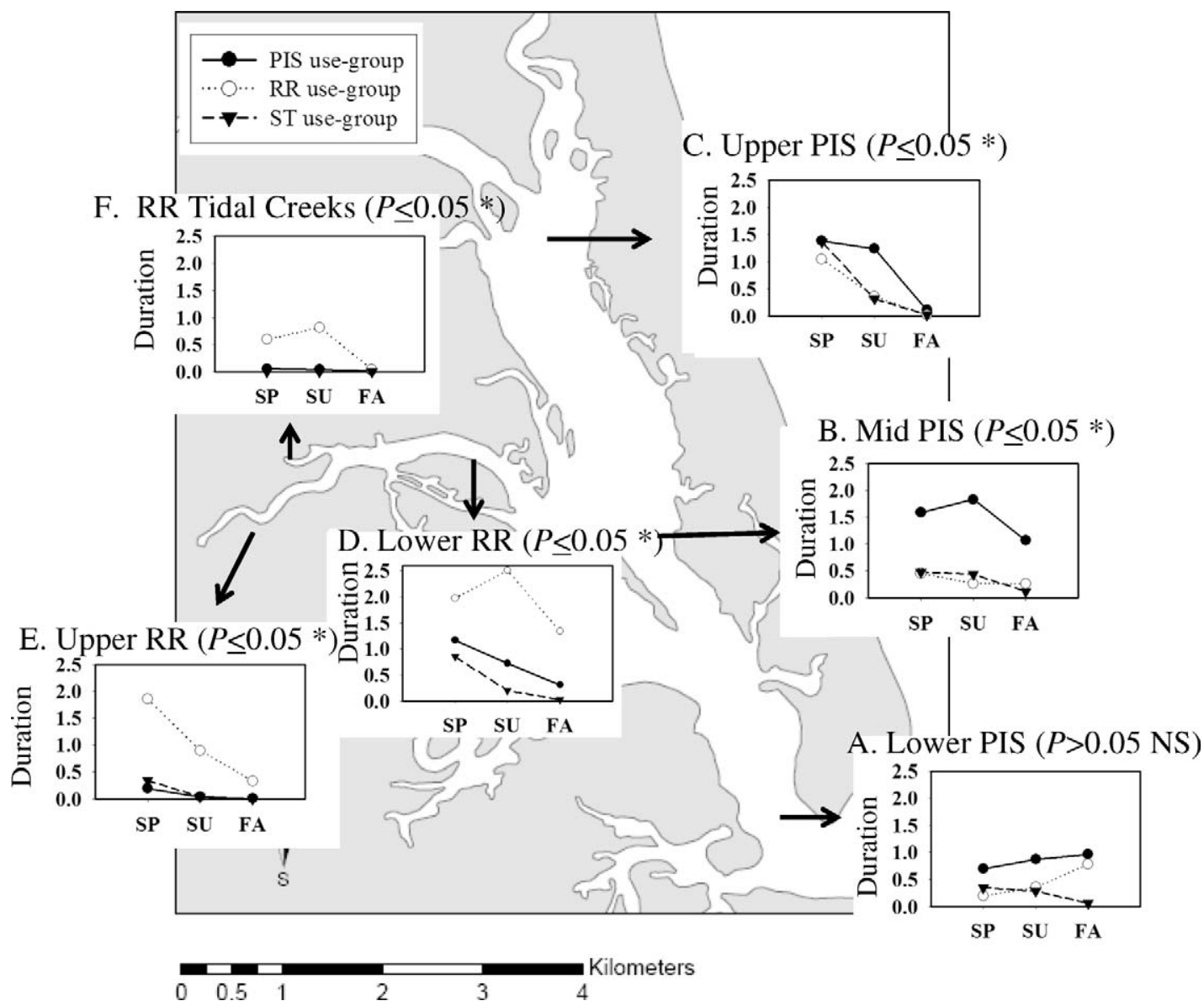

Figure 7.- Seasonal use of six reaches in Plum Island Estuary (PIE), Massachusetts, by three use-groups (foraging contingents) of striped bass tagged in 2006: (A) lower Plum Island Sound (PIS) reach; (B) middle PIS reach; (C) upper PIS reach; (D) lower Rowley River (RR) reach; (E) upper RR reach; and (F) RR tidal creeks reach. Season is shown on the $x$-axis $\left(\mathrm{SP}=\right.$ spring, $\mathrm{SU}=$ summer, and $\mathrm{FA}=$ fall); mean standardized duration (h) after a $\log _{10}$ transformation is shown on the $y$-axis. Use-groups are the PIS use-group (solid circles; present in PIE > $30 \mathrm{~d}$ ), the RR use-group (open circles; present in PIE > $30 \mathrm{~d}$ ), and the short-term visitor (ST) use-group (inverted triangles; present in PIE $<30 \mathrm{~d}$ ). An asterisk next to the reach name indicates that repeated-measures ANOVA was statistically significant for that reach $(P \leq 0.05)$.

arrived together, tagged fish might have settled into similar areas, with the first fish to arrive occupying the most desirable habitat. Although date of tagging (known) is not the same as date of arrival (unknown), date of tagging did not differ across use-groups. We also hypothesized that based on schooling behavior, use-groups might stay together. However, individuals within each use-group did not depart from PIE at the same time. Furthermore, use-groups did not migrate along the same route; instead, individuals from all usegroups were detected in coastal arrays on different days (T. Savoy, D. Fox, and H. Brundage, personal communication). We further hypothesized that larger fish may have used one area, while smaller fish used another. However, fish in the three use-groups did not differ in size. Consequently, date of tagging in PIE, departure date from PIE, and fish size do not explain how individual fish aggregated into different usegroups and then used distinct parts of the estuary.

Our use-groups were similar to spawning and migratory contingents (Clark 1968; Secor et al. 2001) originally defined by Clark (1968) as a unique group of striped bass that "engage in a common pattern of seasonal migrations between feeding areas, wintering areas, and spawning areas." Within contingents, migratory shifts occur, suggesting that these designations need not remain static over the life of the fish (Wingate and Secor 2007). Able and Grothues (2007) 
identified four different behaviors of striped bass in the Mullica River-Great Bay Estuary (resident, seasonal inlet, seasonal estuary, and seasonal river) but did not use the term "contingents" to describe these differences. Although Grothues et al. (2009) suggested that the striped bass in their study were part of migratory contingents originating elsewhere, our study of migratory striped bass in PIE is the first to identify individual striped bass as foraging contingents based on their distinct use of a nonnatal estuary.

\section{Implications for Migratory Behavior}

Coastal migratory striped bass might move seasonally between their spawning, foraging, and overwintering grounds in two ways. First, striped bass may stop in various estuaries briefly on their migrations north and south without staying long in any one location (Able and Grothues 2007; Grothues et al. 2009). In fact, this pattern might explain the behavior of some of our short-term visitors, which moved through PIE in less than $30 \mathrm{~d}$. Alternatively, striped bass could stay for an extended period of time in a single estuary, a behavior that would allow them to "learn" about and adapt to specific biophysical characteristics of the estuary (e.g., what prey are available, where and when prey congregate). These two alternative movement and foraging patterns can have very different implications for predators, local prey, and management strategies. Increasing our knowledge of these within- and acrossestuary movements and residence patterns has the potential to substantially improve our understanding and management of migratory striped bass.

\section{Acknowledgments}

This research was administered through the Massachusetts Cooperative Fish and Wildlife Research Unit, an association among the U.S. Geological Survey, the Department of Natural Resources Conservation (University of Massachusetts), the Massachusetts Division of Marine Fisheries, the Massachusetts Division of Fisheries and Wildlife, and the Wildlife Management Institute. We thank the many people that helped with fieldwork, and we thank the School of Marine Sciences (University of Massachusetts) and the Massachusetts Marine Fisheries Institute. The comments of Steve Cadrin, Greg Skomal, Thomas Grothues, and three anonymous reviewers improved the quality of the manuscript. Joe Smith assisted with the cluster analysis. Cristina Kennedy assisted with line drawings. We also thank the following researchers whose telemetry work in other areas along the Atlantic coast provided valuable insight into where our striped bass traveled: Tom Savoy, Dewayne Fox, Hal Brundage, and Ilene Eberly (Wetlands Institute). Reference to trade names does not imply endorsement by the U.S. Government.

\section{References}

Able, K. W., and T. M. Grothues. 2007. Diversity of estuarine movements of striped bass (Morone saxatilis): a synoptic examination of an estuarine system in southern New Jersey. Fishery Bulletin 105:426-435.

Berggren, T. J., and J. T. Lieberman. 1978. Relative contribution of Hudson, Chesapeake, and Roanoke striped bass, Morone saxatilis, stocks to Atlantic coast fishery. Fishery Bulletin 76:335-345.

Bjorgo, K. A., J. J. Isley, and C. S. Thomason. 2000. Seasonal movement and habitat use by striped bass in the Combahee River, South Carolina. Transactions of the American Fisheries Society 129:1281-1287.

Boreman, J., and R. R. Lewis. 1987. Atlantic coastal migration of striped bass. Pages 331-339 in M. J. Dadswell, R. J. Klauda, C. M. Moffitt, R. L. Saunders, R. A. Rulifson, and J. E. Cooper, editors. Common strategies of anadromous and catadomous fishes. American Fisheries Society, Symposium 1, Bethesda, Maryland.

Bridger, C. J., and R. K. Booth. 2003. The effects of biotelemetry transmitter presence and attachment procedures on fish physiology and behavior. Reviews in Fisheries Science 11:13-34.

Carmichael, J. T., S. L. Haeseker, and J. E. Hightower. 1998. Spawning migration of telemetered striped bass in the Roanoke River, North Carolina. Transactions of the American Fisheries Society 127:286-297.

Clark, J. 1968. Seasonal movements of striped bass contingents of Long Island Sound and the New York Bight. Transactions of the American Fisheries Society 97:320-343.

Clements, S., D. Jepsen, and M. Karnowski. 2005. Optimization of an acoustic telemetry array for detecting transmitter-implanted fish. North American Journal of Fisheries Management 25:429-436.

Collette, B. B., and G. Klein-MacPhee. 2002. Bigelow and Schroeder's fishes of the Gulf of Maine, 3rd edition. Smithsonian Institution Press, Washington, D.C.

Cooke, S. J., C. D. Suski, K. G. Ostrand, B. L. Tufts, and D. H. Wahl. 2004. Behavioral and physiological assessment of low concentrations of clove oil anesthetic for handling and transporting largemouth bass (Micropterus salmoides). Aquaculture 239:509-529.

Coutant, C. C., and D. L. Benson. 1990. Summer habitat suitability for striped bass in Chesapeake Bay: reflections on a population decline. Transactions of the American Fisheries Society 119:757-778.

Deegan, L. A., and R. H. Garritt. 1997. Evidence for spatial variability in estuarine food webs. Marine Ecology Progress Series 147:31-47.

Dorazio, R. M., K. A. Hattala, C. B. McCollough, and J. E. Skjeveland. 1994. Tag recovery estimates of migration of striped bass from spawning areas of the Chesapeake Bay. Transactions of the American Fisheries Society 123:950963.

Fabrizio, M. C. 1987a. Growth-invariant discrimination and classification of striped bass stocks by morphometric and 
electrophoretic methods. Transactions of the American Fisheries Society 116:728-736.

Fabrizio, M. C. 1987b. Contribution of Chesapeake Bay and Hudson River stocks of striped bass to Rhode Island coastal waters as estimated by isoelectric-focusing of eye lens proteins. Transactions of the American Fisheries Society 116:588-593.

Ferry, K. H. 2003. Factors driving distribution of migratory striped bass across Massachusetts estuaries: predatorprey interactions and implications for multispecies management. Wildlife and Fisheries Conservation. Master's thesis. University of Massachusetts, Amherst.

Grothues, T. M., K. W. Able, J. Carter, and T. W. Arienti. 2009. Migration patterns of striped bass through nonnatal estuaries of the U.S. Atlantic coast. Pages 135-150 in A. J. Haro, K. L. Smith, R. A. Rulifson, C. M. Moffitt, R. J. Klauda, M. J. Dadswell, R. A. Cunjak, J. E. Cooper, K. L. Beal, and T. S. Avery, editors. Challenges for diadromous fishes in a dynamic global environment. American Fisheries Society, Symposium 69, Bethesda, Maryland.

Haeseker, S. L., J. T. Carmichael, and J. E. Hightower. 1996. Summer distribution and condition of striped bass within Albemarle Sound, North Carolina. Transactions of the American Fisheries Society 125:690-704.

Harding, J. M., and R. Mann. 2003. Influence of habitat on diet and distribution of striped bass (Morone saxatilis) in a temperate estuary. Bulletin of Marine Science 72:841851.

Hartman, K. J., and S. B. Brandt. 1995. Trophic resource partitioning, diets and growth of sympatric estuarine predators. Transactions of the American Fisheries Society 124:520-537.

Legendre, P., and L. Legendre. 1998. Numerical ecology, 2nd edition. Elsevier, Amsterdam.

Mather, M. E., J. T. Finn, K. H. Ferry, L. A. Deegan, and G. A. Nelson. 2009. Use of non-natal estuaries by migratory striped bass (Morone saxatilis) in summer. Fishery Bulletin 107:329-338.

Nelson, G. A., B. C. Chase, and J. Stockwell. 2003. Food habits of striped bass (Morone saxatilis) in coastal waters of Massachusetts. Journal of Northwest Atlantic Fisheries Science 32:1-25.

Ng, C. L., K. W. Able, and T. M. Grothues. 2007. Habitat use, site fidelity, and movement of adult striped bass in a southern New Jersey estuary based on mobile acoustic telemetry. Transactions of the American Fisheries Society 136:1344-1355.
Pautzke, S. M. 2008. Distribution patterns of migratory striped bass in Plum Island Estuary, Massachusetts. Master's thesis. University of Massachusetts, Amherst.

Rogers, K., and G. C. White. 2007. Analysis of movement and habitat use from telemetry data. Pages 625-676 in C. S. Guy and M. L. Brown, editors. Analysis and interpretation of freshwater fisheries data. American Fisheries Society, Bethesda, Maryland.

Quinn, G. P., and M. J. Keough. 2002. Experimental design and data analysis for biologists. Cambridge University Press, New York.

Secor, D. H., J. R. Rooker, E. Zlokovitz, and V. S. Zdanowicz. 2001. Identification of riverine, estuarine, and coastal contingents of Hudson River striped bass based upon otolith elemental fingerprints. Marine Ecology Progress Series 211:245-253.

Sokal, R. R., and F. J. Rohlf. 1995. Biometry: the principles and practice of statistics in biological research. Freeman, New York.

Szedlmayer, S. T., and R. L. Schroepfer. 2005. Long-term residence of red snapper on artificial reefs in the northeastern Gulf of Mexico. Transactions of the American Fisheries Society 134:315-325.

Tupper, M., and K. W. Able. 2000. Movements and food habits of striped bass (Morone saxatilis) in Delaware Bay (USA) salt marshes: comparison of a restored and a reference marsh. Marine Biology 137:1049-1058.

Vallino, J. J., C. S. Hopkinson, and R. H. Garritt. 2005. Estimating estuarine gross production, community respiration and net ecosystem production: a nonlinear inverse technique. Ecological Modelling 187:281-296.

Waldman, J. R., D. J. Dunning, Q. E. Ross, and M. T. Mattson. 1990. Range dynamics of Hudson River striped bass along the Atlantic coast. Transactions of the American Fisheries Society 119:910-919.

Walter, J. F., A. S. Overton, K. H. Ferry, and M. E. Mather. 2003. Atlantic coast feeding habits of striped bass: a synthesis supporting a coast-wide understanding of trophic biology. Fisheries Management and Ecology 10:349-360.

White, G. C., and R. A. Garrott. 1990. Analysis of wildlife radio-tracking data. Academic Press, San Diego.

Wingate, R. L., and D. H. Secor. 2007. Intercept telemetry of the Hudson River striped bass resident contingent: migration and homing patterns. Transactions of the American Fisheries Society 136:95-104.

Zar, J. H. 1984. Biostatistical analysis. Prentice-Hall, Englewood Cliffs, New Jersey. 